\title{
Characterization and expression profiles of aquaporins (AQPs) 1a and 3a in mud loach Misgurnus mizolepis after experimental challenges
}

\author{
Sang Yoon Lee ${ }^{1}$, Yoon Kwon Nam and Yi Kyung Kim² ${ }^{2 *}$
}

\begin{abstract}
Two distinct cDNAs encoding aquaporins (mmAQPs 1a and 3a) were isolated and characterized from mud loach Misgurnus mizolepis. The identified mud loach AQP cDNAs encode for polypeptides of 260 and 302 amino acids. Topology predictions confirmed six putative membrane-spanning domains connected by five loops and the $\mathrm{N}$ and C-terminal domains being cytoplasmic. The mud loach AQPs 1a and 3a showed broad distribution in multiple tissues including immune-responsive tissues as well as osmoregulatory tissues. Hence, the diversity of AQP distribution and expression possibly indicated its differential functions in the regulation of fluid movement in response to environmental stimuli. The transcription of mmAQP genes was differentially modulated by immune challenges. In particular, the mmAQP3a expression level in the liver was more responsive to immune challenges than that of mmAQP1a. Taken together, fish stimulation or infection resulted in significant modulation of mud loach AQP genes, suggesting potential functional roles of these proteins in piscine pathophysiological process.
\end{abstract}

Keywords: Misgurnus mizolepis, Aquaporins, Lipopolysaccharide, Polyinosinic: polycytidylic acid, Bacterial infection

\section{Background}

Teleostean species possess osmoregulatory system and therefore can overcome salt and water balances along with environmental fluctuations. The epithelia such as gill or intestine are the main site for sensing changes in the salinity, contribute to the alleviation of osmotic stress, and occasionally harbor mechanism to avoid infection (Fiol and Kültz 2007). According to change in the surrounding environment, the macromolecules, such as proteins, trigger complex responses, e.g., cell volume change, changes in cytoskeletal organization or whole tissue remodeling (Fiol and Kültz 2007; Henry et al. 2003).

Aquaporins (AQPs) are important mediators of the movement of water and other small solutes and cell volume regulation. At least 13 aquaporin isoforms have been identified in different organisms ranging from

\footnotetext{
*Correspondence: yikyung1118@gwnu.ac.kr

${ }^{2}$ Department of Marine Biotechnology, Gangneung-Wonju National University, 7 Jukheon-gil, Gangneung, Gangwon-do 25457, South Korea

Full list of author information is available at the end of the article
}

bacteria to humans (Kozono et al. 2003; King et al. 2004) and are categorized into three subfamilies on the basis of their substrate permeability: water-selective aquaporins, aquaglyceroporin (which is permeable to glycerol and certain small, uncharged solutes), and unorthodox subgroup (Ishibashi et al. 2011). The AQPs are ubiquitously expressed in a number of somatic tissues such as the gills, kidney, eye, skeletal muscle, and lung. In addition to their well-established osmoregulatory function, AQPs appear to play important roles in physiological processes including neural signal transduction, skin hydration, brain swelling, and cell migration (Zhu et al. 2011; Verkman 2012). Furthermore, considering its presence in immune-mediated cell, AQPs might also have potential functional role in linkage between unfavorable water flux through its activities and the epithelial barrier immune system (Zhu et al. 2011).

The existence of AQP expression in different tissues clearly indicates its potential functional role in a wide range of biological processes (Gomes et al. 2009; 
Watanabe et al. 2009; Boj et al. 2015). In freshwater prawn Macrobrachium rosenbergii, change in salinity has showed a direct or indirect effect on the respiratory metabolism, mortality, growth, and even immune response later (Cheng and Chen 2000; Moshtaghi et al. 2016). To date, extensive studies have been conducted on a number of fish species to investigate tissuespecific functional roles of AQPs under different salinity environments (Cutler and Cramb 2000; Watanabe et al. 2005; Giffard-Mena et al. 2007; Kim et al. 2010; Choi et al. 2013). In addition, many AQP isoforms have been detected in tissues that are not directly involved in osmoregulation, as evidenced by several studies (Watanabe et al. 2009; Kim et al. 2014; Madsen et al. 2014; Boj et al. 2015). However, functional roles of piscine aquaporin genes with regard to immune or bacterial challenges have still remained unexplored. The limited information may hinder a comprehensive understanding on the coordinated role of AQP isoforms in the maintenance of physiological homeostasis.

Mud loach Misgurnus mizolepis (Teleostei; Cypriniformes) is a promising candidate for freshwater aquaculture whose market demand is gradually increasing in Korea. In addition to its commercial importance, mud loach has the potential to be used as an experimental model animal for investigating various types of theoretical and practical issues. Some interesting biological features of this species include small adult size, high fecundity, year around spawning capability under controlled conditions, and relatively well-established techniques for its genetic manipulation (Nam et al. 2011; Cho et al. 2012). Considering these facts, mud loach could be an ideal model for investigating the functional roles of the AQPmediated cellular process in the pathophysiological situation.
Edwardsiella tarda was chosen for this study because it has been demonstrated as a potential pathogen capable of causing disease and stimulating the immune responses in mud loach (Lee et al. 2011; Nam et al. 2011). In the species most commonly associated with E. tarda infection, the disease is a generalized septicemia with clinical sign including extensive skin lesions, bloody ascites in abdominal cavity, and damage to internal organs (Plumb 1999).

In line with our long-term goal for comprehensive understanding on the osmophysiology and innate immunity of mud loach, the objective of this study was to examine the expression patterns of AQP genes with regard to immunostimulant or bacterial infection. In the current study, we focused on AQPs 1a and $3 \mathrm{a}$ from mud loach, genetically characterized two aquaporin isoforms, and examined their expression patterns in response to immune stimulatory challenges.

\section{Methods \\ Isolation of mud loach aquaporin 1a and 3a CDNAs}

Mud loach $M$. mizolepis expressed sequence tag database (conducted from total RNA) was surveyed to isolate the cDNA sequence for aquaporin. Several partial mud loach AQP clones showing the high homology to previously known vertebrate AQPs were identified using a homology search in NCBI GenBank. Based on the contig assemblies using Sequencher software (Gene Codes Co., Ann Arbor, MI, USA), two distinct isoforms (designated mmAQP1a and mmAQP3a) were identified from various tissues. The full-length cDNA sequence of each aquaporin gene was confirmed from RT-PCR and/ or vectorette PCR with an SK vector primer (Stratagene, La Jolla, Ca, USA) and specific primer pair sets (mmAQP1a FW/RV [for mmAQP1a] or mmAQP3a $\mathrm{FW} / \mathrm{RV}$ [for $m m A Q P 3 a$ ]) (Table 1). The representative

Table 1 List of oligonucleotide primers used in this study

\begin{tabular}{|c|c|c|c|}
\hline Primer name & Sequence $\left(5^{\prime}-3^{\prime}\right)$ & Thermal cycling conditions & Application \\
\hline mmAQP1a FW & CAGAAATCTCCACATTACCAGC & \multirow{4}{*}{$\begin{array}{l}35 \text { cycles at } 94^{\circ} \mathrm{C} \text { for } 20 \mathrm{~s}, 58^{\circ} \mathrm{C} \text { for } 20 \mathrm{~s} \text {, } \\
72^{\circ} \mathrm{C} \text { for } 1.5 \mathrm{~min} \text {, followed by a final } \\
\text { elongation at } 72^{\circ} \mathrm{C} \text { for } 3 \mathrm{~min}\end{array}$} & \multirow[t]{4}{*}{ Isolation of mud loach aquaporin cDNAs } \\
\hline mmAQP1a RV & TCCTGAGGTACATACTGATTC & & \\
\hline mmAQP3a FW & ACACACGTTCAAGGGAAAGC & & \\
\hline mmAQP3a RV & CTGGCTGGATTCACAGCATA & & \\
\hline mm18S rRNA RV & GGTTTCCCGTGTTGAGTCAA & Reverse transcription at $37^{\circ} \mathrm{C}$ for $60 \mathrm{~min}$ & Preparation of normalization control \\
\hline q-mmAQP1a FW & ATGAGAGTGCTGGTCTCTGG & \multirow{6}{*}{$\begin{array}{l}45 \text { cycles at } 94{ }^{\circ} \mathrm{C} \text { for } 20 \mathrm{~s}, 60^{\circ} \mathrm{C} \text { for } 20 \mathrm{~s} \\
\text { and } 72{ }^{\circ} \mathrm{C} \text { for } 20 \mathrm{~s}\end{array}$} & \multirow{6}{*}{$\begin{array}{l}\text { Real-time PCR assay of mud loach } \\
\text { aquaporin mRNAs Real-time PCR assay } \\
\text { of } 18 \mathrm{~S} \text { rRNA control }\end{array}$} \\
\hline q-mmAQP1a RV & AAAGACAGCTTCACAATTGC & & \\
\hline q-mmAQP3a FW & TATGGAGGAGAATGTGAAGC & & \\
\hline q-mmAQP3a RV & AATCTGGAGATGTGCAGCGT & & \\
\hline q-mm18S rRNA FW & AAGCTCGTAGTTGGATCTCG & & \\
\hline q-mm18S rRNA RV & CCTAGCTGCGGTATTCAGGC & & \\
\hline
\end{tabular}

Each PCR amplification reaction was performed with an initial denaturation step at $94{ }^{\circ} \mathrm{C}$ for 2 min 
cDNA sequences for each AQP isoform were determined with multiple PCR clones $(n \geq 6)$ and/or amplified PCR products.

\section{Bioinformatic sequence analysis}

Protein-coding sequences for each AQP isoform were obtained using the open reading frame (ORF) finder (https://www.ncbi.nlm.nih.gov/orffinder/) (Wheeler et al. 2003). The molecular mass and theoretical isoelectric point ( $\mathrm{pI}$ ) value were computed using ExPASy ProtParam tool for each isoform (http://web.expasy.org/protparam/) (Gasteiger et al. 2005). We find the corresponding teleostean and human AQPs from BLAST and/or the Ensembl genome browser (http://www.ensembl.org/index.html) to examine their homology. ORFs of mud loach aquaporin were aligned with teleostean and human orthologues using the multiple sequence alignment programs CLUSTAL W or CLUSTAL X 1.81 (Thompson et al. 1994; Chenna et al. 2003). The information about GenBank accession numbers or Ensembl codes for aquaporin sequences are provided in Table 2. Topology prediction for deduced amino acid sequences of AQPs was performed with the software TMHMM (http://www.cbs.dtu.dk/services/TMHMM/) (Krogh et al. 2001).
Preparation of tissue samples for basal expression assay For the tissue distribution assay of mmAQP transcripts, ten somatic tissues (brain, eye, fin, gill, heart, intestine, kidney, liver, skeletal muscle, and spleen) and two gonad tissues (ovary and testis) were derived from 12 healthy individuals (average body weight $=9.3 \pm 2.5 \mathrm{~g}$ ). Upon surgically removed, biological samples were immediately frozen on dry ice and stored at $-80{ }^{\circ} \mathrm{C}$ until use.

\section{Immune challenges}

To examine whether the expression of $\mathrm{mmAQP}$ genes is induced by inflammatory stimuli and immune challenge, lipopolysaccharide (LPS; Escherichia coli 0111:B4) or polyinosinic: polycytidylic acid [poly(I:C)] injection and bacterial challenge ( $E$. tarda; Gram negative) (Kwon et al. 2005) were performed in vivo. First, LPS (Sigma-Aldrich, St Louis, MO, USA; $5 \mu \mathrm{g} / \mathrm{g}$ body weight $[\mathrm{BW}]$ ) or poly(I:C) (Sigma-Aldrich, $25 \mu \mathrm{g} / \mathrm{g} \mathrm{BW}$ ) was injected intraperitoneally into fish individuals $(10.5 \pm 2.1 \mathrm{~g} ; n=8$ for each group). Saline control $(n=8)$ were done with this study. Injection volume was $100 \mu \mathrm{L}$. After injection, each group was allocated into each $60-\mathrm{L}$ tanks at $25^{\circ} \mathrm{C}$ and no feed was supplied during experimental period. For LPS and poly(I:C) challenges, immune-relevant

Table 2 Amino acid sequence identities of mud loach AQPs 1a and 3a with other orthologues

\begin{tabular}{|c|c|c|c|c|}
\hline & Species & Gene name & Accession no. & Identity (\%) \\
\hline \multirow[t]{12}{*}{ mmAQP1a } & Oryzias dancena & AQP1 & AB759557 & 80 \\
\hline & Osmerus mordax & AQP1a & ACO09149 & 80 \\
\hline & Danio rerio & AQP1a & NP_996942 & 87 \\
\hline & Acanthopagrus schlegelii & AQP1a & ABO38816 & 80 \\
\hline & Dicentrarchus labrax & AQP1a & $A B \mid 95464$ & 79 \\
\hline & Fundulus heteroclitus & AQP1a & ACl49538 & 80 \\
\hline & Danio rerio & AQP1b & NP_001129154 & 63 \\
\hline & Solea senegalensis & AQP1b & AAV34612 & 57 \\
\hline & Salmo salar & AQP1b & ACI33306 & 72 \\
\hline & Sparus aurata & AQP1b & EF011740 & 61 \\
\hline & Anguilla anguilla & AQP1b & CAD92028 & 63 \\
\hline & Homo sapiens & AQP1 & BAG70089 & 60 \\
\hline \multirow[t]{10}{*}{ mmAQP3a } & Oryzias dancena & AQP3 & AB759557 & 70.4 \\
\hline & Danio rerio & AQP3a & EU341833 & 84.8 \\
\hline & Oreochromis mossambicus & AQP3a & BAD20708 & 72.2 \\
\hline & Dicentrarchus labrax & AQP3a & ABG36519 & 69.9 \\
\hline & Fundulus heteroclitus & AQP3a & ACl49539 & 68.8 \\
\hline & Danio rerio & AQP3b & EU341832 & 67.9 \\
\hline & Anguilla anguilla & AQP3b & CAC85286 & 73.6 \\
\hline & Anguilla japonica & AQP3 & BAH89253 & 72 \\
\hline & Astyanax mexicanus & AQP3 & XP_007238017 & 69 \\
\hline & Homo sapiens & AQP3 & AB001325 & 64.7 \\
\hline
\end{tabular}


tissues (kidney, intestine, liver, and spleen) were surgically removed from three individuals in each group at $24 \mathrm{~h}$ post challenge.

On other hand, the bacterial challenge was carried out by injecting $1 \times 10^{6}$ cell of $E$. tarda suspended in $100 \mu \mathrm{L}$ of phosphate-buffered saline (PBS, pH 7.4) intraperitoneally into each individual. Twenty-four individuals (same-size as above) were given E. tarda injection, and other 24 individuals were given PBS alone as a control group. Each group (E. tarda- or PBS-injected) was transferred to each $100-\mathrm{L}$ tank at $25^{\circ} \mathrm{C}$, and tissue samples were obtained individually from three randomly chosen fish belonging to each tank at 24,48 , and $72 \mathrm{~h}$ post injection, respectively. Tissue samples were harvested, frozen, and stored as described above.

\section{RT-PCR analysis of mmAQP transcripts}

Total RNA was extracted from dissected tissues using the RNeasy ${ }^{\circ}$ Plus Micro Kit (Qiagen, Hilden, Germany) including DNase I treatment step. An aliquot of the total RNA $(2 \mu \mathrm{g})$ was reverse transcribed into cDNA in a reaction volume of $20 \mu \mathrm{l}$ using the Omniscript ${ }^{\circ}$ Reverse Transcription Kit (Qiagen). The reverse transcription reaction include an oligo- $\mathrm{d}(\mathrm{T})_{20}$ primer $(1 \mu \mathrm{M}$ final concentration) and a mud loach $18 \mathrm{~S}$ rRNA $(0.1 \mu \mathrm{M})$ reverse primer, as described by Cho et al. (2012). The use of $18 \mathrm{~S}$ rRNA as the internal standard can be a valuable alternative for quantifying genes of interest, but it may reduce the variation of expression.

The reaction conditions were performed according to the manufacturer's protocol. RT-PCR reactions were performed in $25-\mu \mathrm{L}$ reaction volumes including $2-\mu \mathrm{l} \mathrm{cDNA}$, $2-\mu \mathrm{l}$ primers, $6.5-\mu \mathrm{l}$ distilled water, and $12.5-\mu \mathrm{l} 2 \times \mathrm{iQ}$ SYBR Green Supermix (Bio-Rad, Hercules, CA, USA). Reaction performed on the iCycler iQ Real-time Detection System (Bio-Rad). The plasmid DNAs containing the amplified parts of target mRNAs were prepared as standard samples. The 231-bp (for AQP1a) and 208-bp (for AQP3a) aquaporin gene fragments were amplified with the specific primer pairs, q-mmAQP1a-FW/RV and q-mmAQP3a-FW/RV, respectively (Table 1). Basal expression level of $A Q P$ transcripts in tissue types was represented based on $\triangle \mathrm{Ct}$ (Ct of the AQP gene subtracted from the $\mathrm{Ct}$ of the $18 \mathrm{~s}$ RNA gene). On the other hand, the relative expressions of AQP transcripts in the stimulated groups were expressed as the fold change to nontreated control by using the formula $2^{-\Delta \Delta \mathrm{Ct}}$ (Kubista et al. 2006; Schmittgen and Livak 2008). Each reaction was performed at least in triplicates.

\section{Statistical analysis}

Numerical data were expressed as means \pm S.E.M. Statistical differences were determined by one-way analysis of variance (ANOVA), followed by Duncan's multiple range tests. All statistical analysis were performed using software SPSS version 10.0 (SAS Inc., Cary, NC, USA), and difference was considered to be significant when $P<0.05$.

\section{Results \\ Characteristics of mud loach AQP cDNA 1a and 3a isoforms}

We isolated two distinct aquaporin genes from the mud loach. They are 1230 and $1609 \mathrm{bp}$ in the length and contain ORFs of 780 and 906 bp (excluding the termination codon) encoding a polypeptides of 287 and 306 amino acid, respectively. The calculated molecular masses of each isoform are 27.3 and $32.8 \mathrm{kDa}$, with theoretical $\mathrm{pl}$ values of 6.05 and 6.15 , respectively. The nucleotide sequences of the two AQP cDNA sequences have been assigned on GenBank under the accession numbers AB971265 (mmAQP1a) and AB971266 (mmAQP3a). The mud loach AQP isoforms showed very lower level of sequence homology (18\%) with each other. From multiple sequence alignments with other orthologs, the amino acid sequence of mud loach AQPs shared considerable identities with those from teleostean AQPs (Table 2). The basic features of typical AQP channel structure were observed in mud loach AQP1a and AQP3a isoforms. According to topology prediction for these proteins, those proteins possess six potential transmembrane helices connected by five loops. Both the amino and carboxyl termini are extended into the cytoplasmic side (Fig. 1). Importantly, the two identical asparagine-proline-alanine (NPA) motifs are located in the second and fifth loops, which are the pore-forming signature motifs for AQPs playing a crucial role in the water uptake (Ishibashi et al. 2011). In mmAQP1a, a cysteine residue in position 180, proximal to the Cterminal NPA motif, is possibly pivotal for the inhibition of water permeability by mercurial reagent (Preston et al. 1993).

\section{Basal expression assay of mud loach AQPs $1 \mathrm{a}$ and $3 \mathrm{a}$} Under the present RT-PCR conditions, AQP1a and AQP3a transcripts were ubiquitously distributed in all tissue types examined, although the basal levels were significantly different among tissues. In particular, the mRNA levels of AQP1a were higher in non-osmogulatory tissues, brain, eye, heart, and spleen than osmoregulatory tissues, for example, the intestine, kidney, and gill. On the other hand, AQP3a transcripts in non-stimulated fish were detectable markedly in fin, followed by gill, eye and intestine (Fig. 2).

\section{AQP gene expression profiles after immune challenge}

The mud loach AQP1a mRNA was rapidly induced by LPS injection in all tissues, and the fold change relative to the expression level in the saline-injected control was 


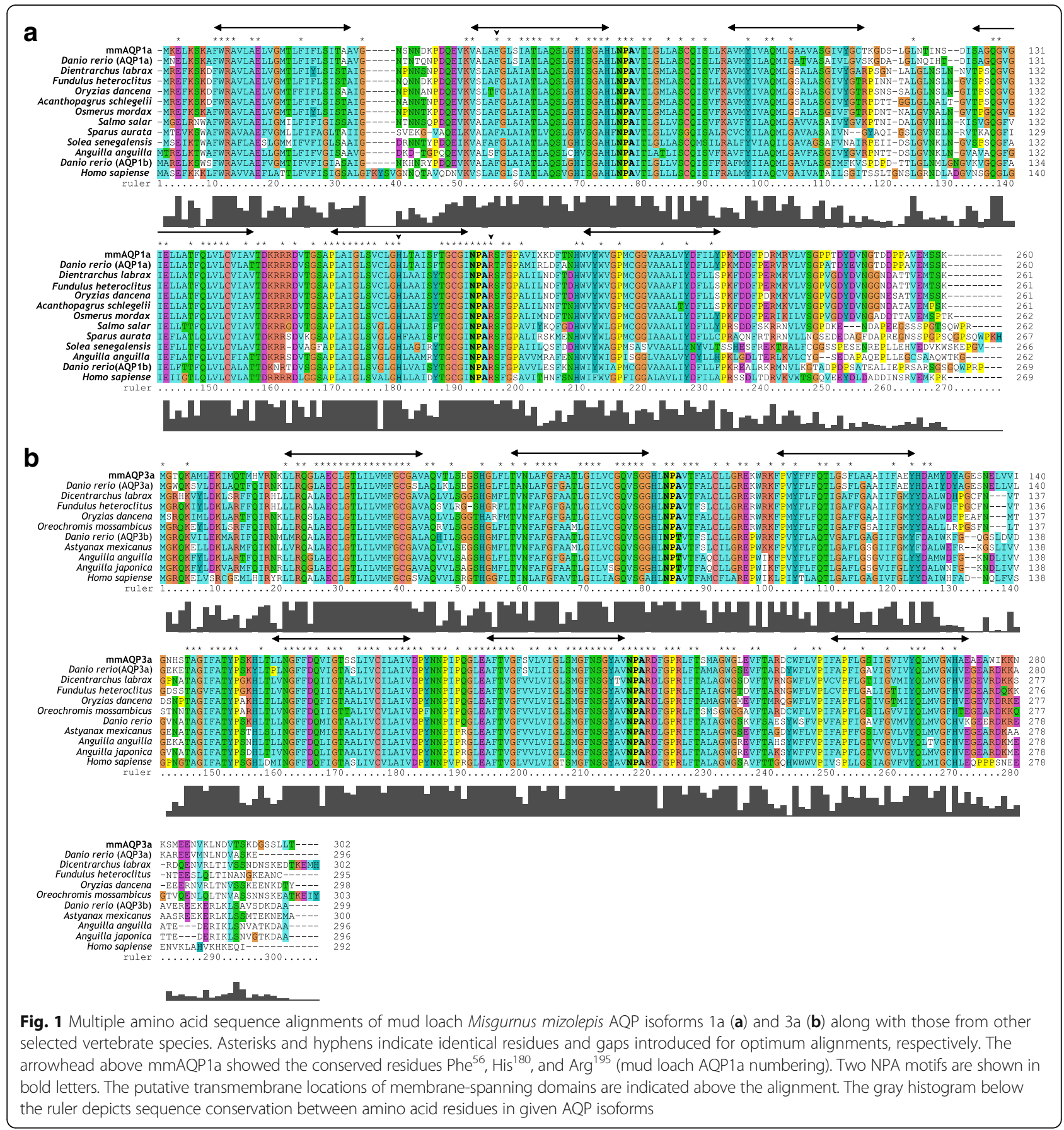

higher in the liver (1.3-fold) than in the intestine (0.2fold), kidney (0.5-fold), and spleen (0.4-fold) (Fig. 3a). Also, the transcriptional response of AQP1a to poly(I:C) at $24 \mathrm{~h}$ post-injection showed levels highest in the kidney (1.6-fold) compared with other tissues (Fig. 3a). In contrast, the LPS injection significantly stimulated the transcription of AQP3a, which were greatest in the intestine (15.9-fold), followed by the liver (6.14-fold) and spleen (1.05-fold) (Fig. 3b). Moreover, the liver showed a predominant increase in $\mathrm{mmAQP3a}$ transcripts of 23.38-fold induction by poly(I:C) stimulation.

\section{AQP gene profiles after bacterial challenge}

An in vivo bacterial injection was conducted with the known pathogen E. tarda (Gram negative; FSW910410), which causes edwardsiellosis in mud loach (Fig. 4). The expression patterns of mud loach AQP1a and AQP3a transcripts differed in the intestine, kidney, liver, and 


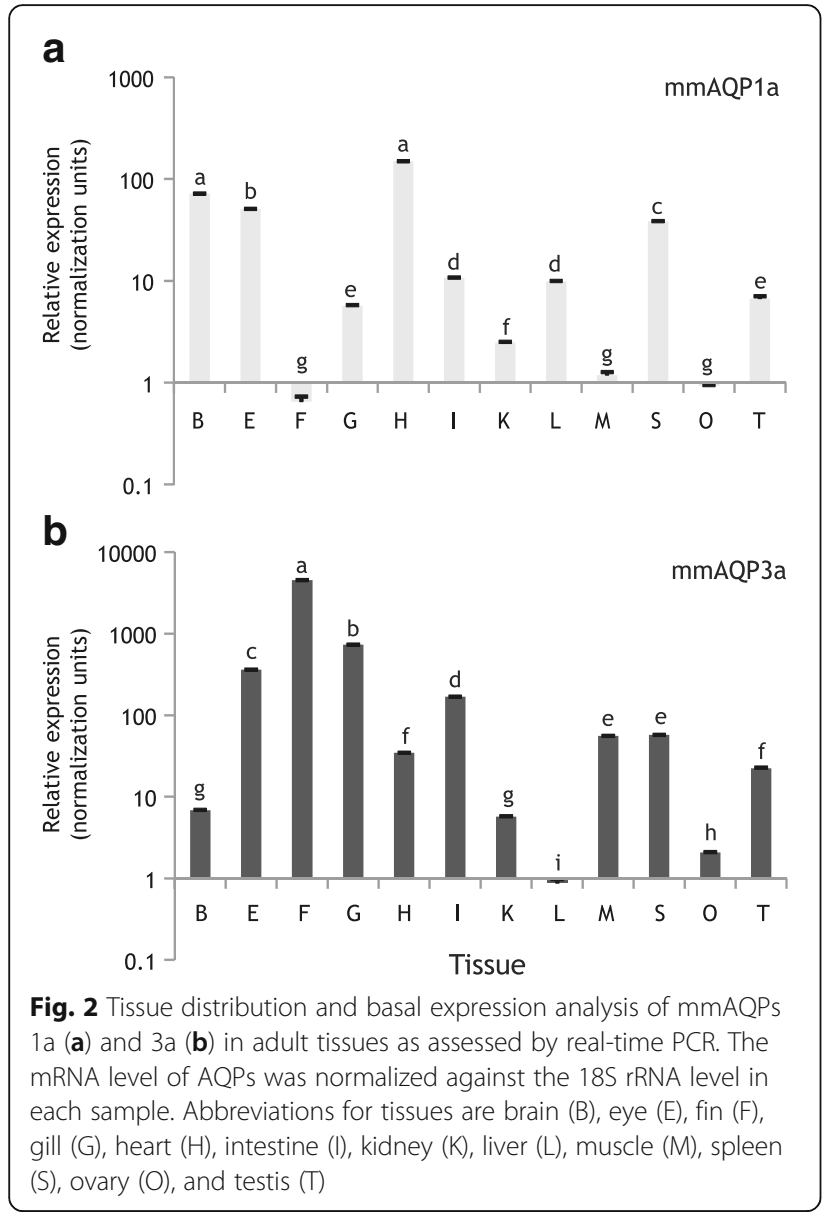

spleen. The transcriptions of mud loach AQP1a and AQP3a in the intestine were significantly decreased by E. tarda challenges, and the reduction of intestinal AQP1a and AQP3a expressions was clearly timedependent. Compared to that of intestinal response, in the kidney, the expression of the two isoform genes was modulated in opposite directions at each time point examined. In the liver, AQP1a isoform was less modulated by bacterial injection; no significant changes were evident during experimental period; instead, the mmAQP3a transcripts were responsive to $E$. tarda challenges, and the maximum induction of AQP3a expression was observed at $72 \mathrm{~h}$ after bacterial injection. The spleen showed the differential induction of the two AQP transcripts during E. tarda challenge in this study. The splenic mRNA levels of mmAQP1a were highly elevated (up to seven fold relative to the saline-injected controls) at $48 \mathrm{~h}$ post injection (hpi) and rapidly deceased at 72 hpi. In contrast, the mmAQP3a transcripts were slightly but significantly induced in time-dependent manner.

\section{Discussion}

We cloned two cDNAs encoding AQPs 1a and 3a from mud loach. The identified AQPs possess six a $\quad \mathrm{mmAQP1a}$

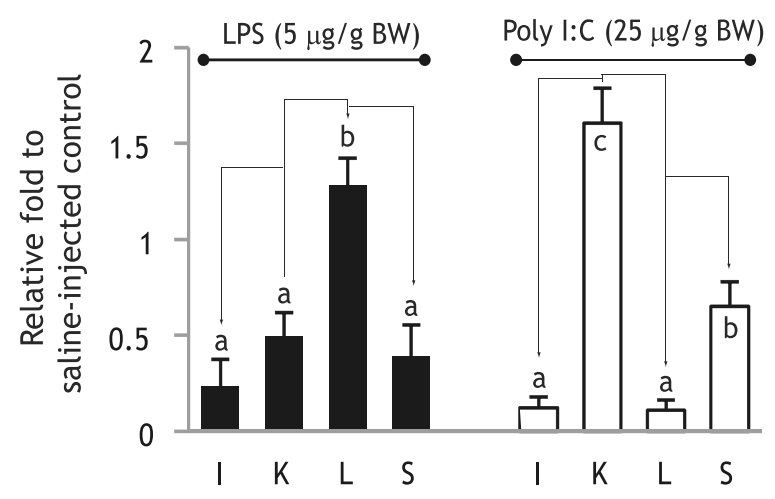

b $\quad \mathrm{mmAQP3a}$

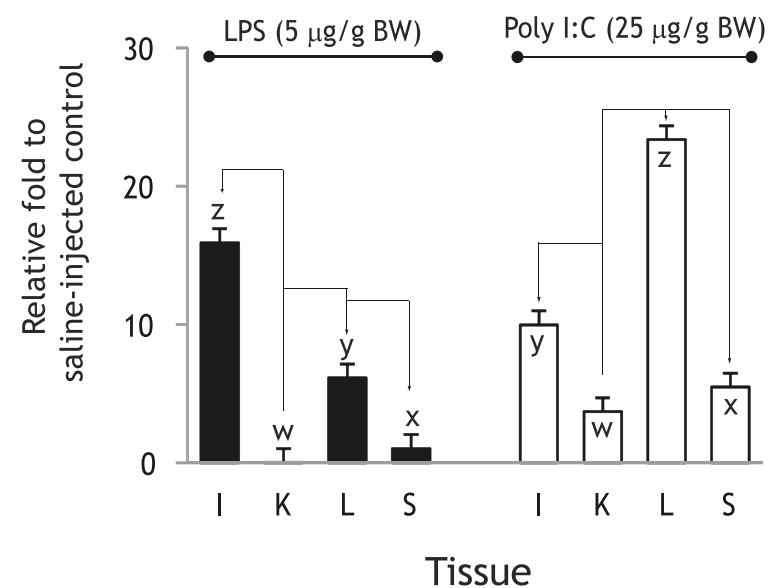

Fig. 3 Transcriptional responses of the mud loach AQPs 1a (a) and 3a (b) to immunostimulant exposures in differential tissues as assessed by real-time RT-PCR analysis. Levels of AQP isoforms in immunostimulantexposed groups are expressed as fold changes relative to those in non-exposed control group after normalization against $18 \mathrm{~S}$ rRNA standard. Mean \pm SDs with same letters (a-c for mmAQP1a and $x-$ z for mmAQP3a) are not significantly different based on ANOVA followed by Duncan's multiple range tests

transmembrane domains which are found in known major intrinsic protein (MIP) structures as well as among aquaporin (Borgnia et al. 1999). The traditional NPA sequences have been harbored to form a characteristic pore between the membrane bilayer (Nielsen et al. 1999). These findings suggest that AQPs from mud loach function as water channels that facilitate passage of water and other small solutes through membrane, although we did not investigate the functional role in detail.

In the present study, transcripts encoding $\mathrm{AQP} 1$ a were detectable in a wide array of tissues of mud loach, which has also been observed in marine medaka Oryzias dancena, Japanese medaka O. latipes, zebrafish, Japanese eel Anguilla japonica and black porgy, Acanthopagrus 

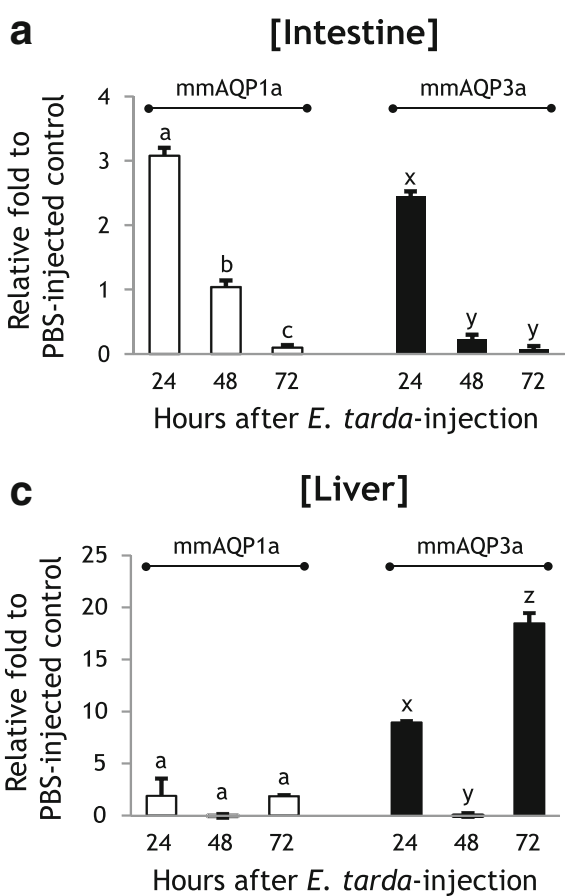

b [Kidney]

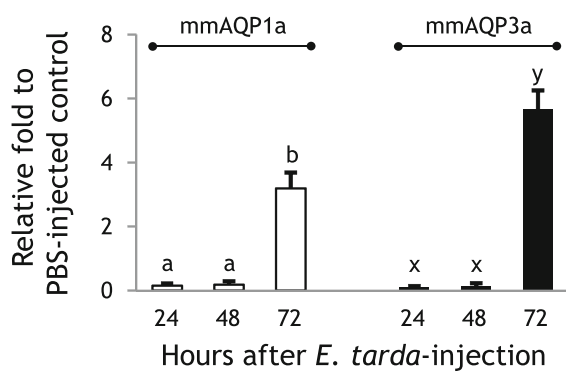

d

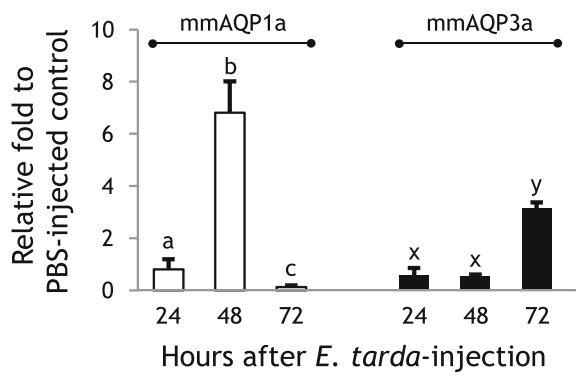

Fig. 4 Differential modulation of mud loach AQP isoforms by Edwardsiella tarda challenges (a-d). Relative AQP gene expression to reference gene was represented by fold change to control group. Mean \pm SDs with same letters are not significantly different based on ANOVA followed by Duncan's multiple range tests

schlegeli (An et al. 2008; Tingaud-Sequeira et al. 2010; Kim et al. 2010, 2014; Madsen et al. 2014). Relatively higher mRNA expression levels were observed in the heart, brain, eye, spleen, and intestine but also present in lower levels in all other tissues examined, which in part may manifest a general expression in erythrocytes and endothelial barriers (Mobasheri and Marples 2004). The higher expression of cardiac mmAQP1a may be a main determinant of its role in myocardial fluid balance, as suggested by Japanese eel and silver sea bream Sparus sarba (Aoki et al. 2003; Deane et al. 2011). The splenic AQP has been considered to be involved in the trafficking of hematopoietic cells (Tyagi and Tangevelu 2010). The branchial AQP1a showed lower expression level, compared to those of osmoregulatory tissues. This result is somewhat contradictory to previous report that the gills of freshwater fish are the main pathway for water transport and can account for approximately $90 \%$ of the total body water influx (Cutler and Cramb 2000; Deane et al. 2011). Although specific mechanism should be investigated in the further study, the branchial AQP1a might act in concert with other homologs (e.g., AQP3a in this study) to prevent cell swelling. The testicular expression of mmAQP1a was noticeable, while lower expressed in ovary. In gilthead sea bream Sparus aurata, the distinct aquaporin paralogs (e.g., AQPs 0a, 1aa, 1ab, $7,8 \mathrm{~b}, 9 \mathrm{~b}$, and $10 \mathrm{~b}$ ) were involved in control of the fluid balance during spermatogenesis (Boj et al. 2015). Hence, these facts suggest that testicular function in the mud loach is potentially associated with fine-tuned water control by aquaporin channel.

The observation of AQP3a in mud loach was comparable to that described for several teleost (Deane and Woo 2006; Tingaud-Sequeira et al. 2010; Kim et al. 2014). With reference to expression levels, mmAQP3a mRNAs were unequivocally predominant in the fin that is not primarily involved in osmoregulatory systems, which could be due to thin epidermis. The pattern observed in this study is similar to that reported in tilapia and medaka (Watanabe et al. 2005; Kim et al. 2014; Madsen et al. 2014). Another noticeable feature in mmAQP3a mRNA levels was observed in gill and eye, which are externally exposed organs in fish. Relatively higher AQP3a abundance in the gill suggested its involvement in possible osmoreception by mitochondrionrich chloride cells (Watanabe et al. 2005). In addition, relatively high level was also found in the spleen, in accordance with several teleost species (Watanabe et al. 2005; Kim et al. 2014). However, mmAQP3a mRNA expression was found at very low level in liver, known as major detoxification organ. This expression pattern is similar to that observed previously in other teleostean fish (Watanabe et al. 2005; Tingaud-Sequeira et al. 2010; Madsen et al. 2014). Thus, the mud loach AQPs 1a and 
3a, in common with other teleostean fish AQPs, exhibited broad distribution in multiple diverse tissues including immune-responsive and mucosal tissues exposed to external environment. Hence, the variety of AQP distribution and expression presumably suggested its differential functions in the regulation of water movement according to environmental stimuli.

Overall, the RT-PCR quantitative analysis with two AQP transcripts showed the significant response to the challenges. The mmAQP1a mRNAs in the liver and kidney were significantly induced by LPS or poly(I:C) injection. In contrast to expression levels of $\mathrm{mmAQP} 1 \mathrm{a}$ transcripts, AQP3a expression was markedly elevated in some but not all tissues examined. In particular, the AQP3a transcript was significantly elevated in the liver or kidney in response to challenge. Furthermore, the significant AQP3a level after poly(I:C) stimulation was striking when compared to basal expression in the liver. Recent study has reported that hepatic AQP3 might be involved in both Kuffer cell migration and proinflammatory cytokine secretion in mammals, reflecting its involvement with immune response (Rodríguez et al. 2011). The expressions of mud loach aquaporin gene under E. tarda stimulus are differentially modulated during experimental period, as in the aforementioned results. The intestinal AQP1a and AQP3a transcript levels showed a significant reduction with time. Apart from serving as the site of nutrient uptake and osmoregulation, the intestine functions as a critical defense barrier to the external environment (Grosell 2011). The intestinal fluid balance in the fish as well as mammalian has been indicated to be cooperated by various factors, including hormones, intestinal contents, inflammatory factors, and feeding (Rombout et al. 2011; Zhu et al. 2016). Thus, the bacterial challenge may either directly or indirectly linked to unfavorable change of water balance in the intestine in the pathophysiological stress. In the kidney, the expression of two isoform genes was modulated in opposite directions in response to $E$. tarda challenge. When considering that the role of kidney in freshwater fish is to produce copious quantities of dilute urine, the significant fluctuation in renal AQP expression after bacterial challenge may be associated with the conditions demonstrating severe edema formation due to renal failure, as evidenced by zebrafish (Kramer-Zucker et al. 2005). Usually, the piscine liver performs not only the basically metabolic function including bile formation and excretion but also macrophage contributor (Paulsen et al. 2003; Wolf and Wolfe 2005). Accordingly, modulation of hepatic AQP3 transcript may result in disruption of physiological homeostasis, for example, bile secretory failure (Lehmann et al. 2008). Collectively, these data suggest that the alteration in AQP transcripts expression, especially AQP3a, may be involved in a significant way in the pathophysiology of fish and should be considered in further studies.

\section{Conclusions}

In current study, we observed ubiquitous distribution of mud loach AQPs in immune-relevant as well as osmoregulatory tissues. Immune challenge-induced changes in expression pattern of AQP3 indicate that this gene has important role to respond to inflammatory disease or condition. Further investigation is needed to decipher the importance of AQPs in dealing with water homeostasis during infection and inflammation in a finer detail.

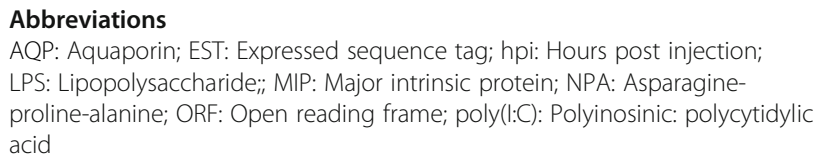

Acknowledgements

We are grateful for the funding by National Research Foundation of Korea.

Funding

This study was supported by the National Research Foundation of Korea (NRF) grant funded by the Korea government (MSIP) (No. 2013R1A1A3013064).

Availability of data and materials

Not applicable.

Authors' contributions

YKK and SYL carried out the molecular biology and expression assay. YKK and YKN designed the study and data evaluation and drafted the manuscript.

All authors read and approved the final manuscript.

Ethics approval and consent to participate

Not applicable.

Consent for publication

Not applicable.

Competing interests

The authors declare that they have no competing interests.

\section{Publisher's Note}

Springer Nature remains neutral with regard to jurisdictional claims in published maps and institutional affiliations.

\section{Author details}

${ }^{1}$ Department of Marine Bio-Materials and Aquaculture, Pukyong National University, Busan 48513, South Korea. 'Department of Marine Biotechnology, Gangneung-Wonju National University, 7 Jukheon-gil, Gangneung,

Gangwon-do 25457, South Korea.

Received: 15 May 2017 Accepted: 2 September 2017

Published online: 27 September 2017

\footnotetext{
References

An KW, Kim NN, Choi CY. Cloning and expression of aquaporin 1 and arginine vasotocin receptor mRNA from the black porgy, Acanthopagrus schlegli: effect of freshwater acclimation. Fish Physiol Biochem. 2008;34:185-94.

Aoki M, Kaneko T, Katoh F, Hasegawa S, Tsutsui N, Aida K. Intestinal water absorption through aquaporin 1 expressed in the apical membrane of mucosal epithelial cells in seawater-adapted Japanese eel. J Exp Biol. 2003:206:3495-505

Boj M, Chauvigné F, Zapater C, Cerdà J. Gonadotropin-activated androgendependent and independent pathways regulate aquaporin expression during teleost (Sparus aurata) spermatogenesis. PLoS One. 2015;10:e0142512.
} 
Borgnia M, Nielsen S, Engel A, Agre P. Cellular and molecular biology of the aquaporin water channels. Annu Rev Biochem. 1999;68:425-58.

Cheng W, Chen JC. Effects of $\mathrm{pH}$, temperature and salinity on immune parameters of the freshwater prawn Macrobrachium rosenbergii. Fish Shellfish Immunol. 2000;10:387-91.

Chenna R, Sugawara H, Koike T, Lopez R, Gibson TJ, Higgins DG, Thompson TD. Multiple sequence alignment with the clustal series of programs. Nucleic Acids Res. 2003;31:3497-500.

Cho YS, Kim BS, Kim DS, Nam YK. Modulation of warm-temperature-acclimationassociated 65-kDa protein genes (Wap65-1 and Wap65-2) in mud loach (Misgurnus mizolepis, Cypriniformes) liver in response to different stimulatory treatments. Fish Shellfish Immunol. 2012;32:662-9.

Choi YJ, Shin HS, Cho SH, Yamamoto Y, Ueda H, Lee J, Choi CY. Expression of aquaporin-3 and -8 mRNAs in the parr and smolt stages of sockeye salmon, Oncorhynchus nerka: effects of cortisol treatment and seawater acclimation. Comp Biochem Physiol A Mol Integr Physiol. 2013;165:228-36.

Cutler CP, Cramb G. Water transport and aquaporin expression in fish. In: Molecular Biology and Physiology of Water and Solute Transport. Springer US; 2000. p. 433-441.

Deane EE, Luk JC, Woo NY. Aquaporin 1a expression in gill, intestine, and kidney of the euryhaline silver sea bream. Front Physiol. 2011;21:2.

Deane EE, Woo NY. Tissue distribution, effects of salinity acclimation, and ontogeny of aquaporin 3 in the marine teleost, silver sea bream (Sparus sarba). Mar Biotechnol (NY). 2006;8:663-71.

Fiol DF, Kültz D. Osmotic stress sensing and signaling in fishes. FEBS J. 2007;274:5790-8

Gasteiger E GA, Duvaud S, Wilkins MR, Appel RD, Bairoch A. Protein identification and analysis tools on the ExPASy server. In: Walker JM, editor. The Proteomics Protocols Handbook. Humana Press; 2005. p. 571-607.

Giffard-Mena I, Boulo V, Aujoulat F, Fowden H, Castille R, Charmantier G, Cramb G. Aquaporins molecular characterization in the sea-bass (Dicentrarchus labrax): the effect of salinity on AQP1 and AQP3 expression. Comp Biochem Physiol A. 2007;148:430-44.

Gomes D, Agasse A, Thiébaud P, Delrot S, Gerós H, Chaumont F. Aquaporins are multifunctional water and solute transporters highly divergent in living organisms. Biochim Biophys Acta. 2009;1788:1213-28.

Grosell M. The role of the gastrointestinal tract in salt and water balance. In: Grosell M, Farrell AP, Brauner CJ, editors. The multifunctional gut of fish. San Diego: Academic; 2011. p. 136-64.

Henry RP, Gehnrich S, Weihrauch D, Towle DW. Salinity-mediated carbonic anhydrase induction in the gills of the euryhaline green crab, Carcinus maenas. Comp Biochem Physiol A Mol Integr Physiol. 2003;136:243-58.

Ishibashi K, Kondo S, Hara S, Morishita Y. The evolutionary aspects of aquaporin family. Am J Phys. 2011;300:R566-76.

Kim YK, Lee SY, Kim BS, Kim DS, Nam YK. Isolation and mRNA expression analysis of aquaporin isoforms in marine medaka Oryzias dancena, a euryhaline teleost. Comp Biochem Physiol A Mol Integr Physiol. 2014;171:1-8.

Kim YK, Watanabe S, Kaneko T, Huh MD, Park SI. Expression of aquaporins 3, 8 and 10 in the intestines of freshwater- and seawater-acclimated Japanese eels Anguilla japonica. Fish Sci. 2010;76:695-702.

King LS, Kozono D, Agre P. From structure to disease: the evolving tale of aquaporin biology. Nat Rev Mol Cell Biol. 2004;5:687-98.

Kozono D, Ding X, Iwasaki I, Meng X, Kamagata Y, Agre P, Kitagawa Y. Functional expression and characterization of an archaeal aquaporin AqpM from Methanothermobacter marburgenesis. J Biol Chem. 2003;278:10649-56.

Kramer-Zucker AG, Wiessner S, Jensen AM, Drummond IA. Organization of the pronephric filtration apparatus in zebrafish requires Nephrin, Podocin and the FERM domain protein mosaic eyes. Dev Biol. 2005;285:316-29.

Krogh A, Larsson B, Von Heijne G, Sonnhammer EL. Predicting transmembrane protein topology with a hidden Markov model: application to complete genomes. J Mol Biol. 2001;305:567-80.

Kubista M, Andrade JM, Bengtsson M, Forootan A, Jonák J, Lind K, Sindelka R, Sjöback R, Sjögreen B, Strömbom L, Ståhlberg A, Zoric N. The real-time polymerase chain reaction. Mol Asp Med. 2006;27:95-125.

Kwon SR, Nam YK, Kim SK, Kim DS, Kim KH. Generation of Edwardsiella tarda ghosts by bacteriophage PhiX174 lysis gene E. Aquaculture. 2005;250:16-21.

Lee SY, Kim DS, Nam YK. Altered expression of mud loach (Misgurnus mizolepis; Cypriniformes) hepcidin mRNA during experimental challenge with nonpathogenic or pathogenic bacterial species. J Fish Pathol. 2011;24:279-87.
Lehmann GL, Carreras FI, Soria LR, Gradilone SA, Marinelli RA. LPS induces the TNF-amediated downregulation of rat liver aquaporin-8: role in sepsis-associated cholestasis. Am J Physiol Gastrointest Liver Physiol. 2008;294:G567-75.

Madsen SS, Bujak J, Tipsmark CK. Aquaporin expression in the Japanese medaka (Oryzias latipes) in freshwater and seawater: challenging the paradigm of intestinal water transport? J Exp Biol. 2014;217:3108-21.

Mobasheri A, Marples D. Expression of the AQP-1 water channel in normal human tissues: a semiquantitative study using tissue microarray technology. Am J Phys. 2004;286:C529-37.

Moshtaghi A, Rahi ML, Nguyen VT, Mather PB, Hurwood DA. A transcriptomic scan for potential candidate genes involved in osmoregulation in an obligate freshwater palaemonid prawn (Macrobrachium australiense). Peer J. 2016:4:e2520.

Nam YK, Cho YS, Lee SY, Kim BS, Kim DS. Molecular characterization of hepcidin gene from mud loach (Misgurnus mizolepis; Cypriniformes). Fish Shellfish Immunol. 2011;31:1251-8.

Nielsen S, Kwon TH, Christensen BM, Promeneur D, Frøkiaer J, Marples D. Physiology and pathophysiology of renal aquaporins. J Am Soc Nephrol. 1999:10:647-63.

Paulsen SM, Lunde $H$, Engstad RE, Robertsen B. In vivo effects of $\beta$-glucan and LPS on regulation of lysozyme activity and mRNA expression in Atlantic salmon (Salmo Salar L.). Fish Shellfish Immunol. 2003;14:39-54.

Plumb JA. Edwardsiella Septicaemias. In: Woo PTK, Bruno DW, editors. Fish diseases and disorders, volume 3: viral, bacterial, and fungal infections, vol. 3. Oxon: CAB International; 1999. p. 479-521.

Preston GM, Jung JS, Guggino WB, Agre P. The mercury-sensitive residue at cysteine 189 in the CHIP28 water channel. J Biol Chem. 1993;268:17-20.

Rodríguez A, Catalán V, Gómez-Ambrosi J, García-Navarro S, Rotellar F, Valentí V, Silva C, Gil MJ, Salvador J, Burrell MA, Calamita G, Malagón MM, Frühbeck G. Insulin-and leptin-mediated control of aquaglyceroporins in human adipocytes and hepatocytes is mediated via the PI3K/Akt/mTOR signaling cascade. J Clin Endocrinol Metab. 2011;96:E586-97.

Rombout JH, Abelli L, Picchietti S, Scapigliati G, Kiron V. Teleost intestinal immunology. Fish Shellfish Immunol. 2011;31:616-26.

Schmittgen TD, Livak KJ. Analyzing real-time PCR data by the comparative C(T) method. Nat Protoc. 2008;3:1101-8.

Thompson JD, Higgins DG, Gibson TJ. Clustal W: improving the sensitivity of progressive multiple sequence alignment through sequence weighting, position specific gap penalties and weight matrix choice. Nucleic Acids Res. 1994;22:4673-80

Tingaud-Sequeira A, Calusinska M, Finn RN, Chauvigné F, Lozano J, Cerdà J. The zebrafish genome encodes the largest vertebrate repertoire of functional aquaporins with dual paralogy and substrate specificities similar to mammals. BMC Evol Biol. 2010;10:38.

Tyagi MG, Tangevelu P. A possible role of aquaporin water channels in blood cell migration in spleen; interaction with cluster of differentiation molecules. J Exp Sci. 2010;1:41-2.

Verkman AS. Aquaporins in clinical medicine. Annu Rev Med. 2012;63:303-16.

Watanabe S, Hirano T, Grau EG, Kaneko T. Osmosensitivity of prolactin cells is enhanced by the water channel aquaporin-3 in a euryhaline Mozambique tilapia (Oreochromis mossambicus). Am J Phys. 2009;296:R446-53.

Watanabe S, Kaneko T, Aida K. Aquaporin-3 expressed in the basolateral membrane of gill chloride cells in Mozambique tilapia Oreochromis mossambicus adapted to freshwater and seawater. J Exp Biol. 2005;208:2673-82

Wheeler DL, Church DM, Federhen S, Lash AE, Madden TL, Pontius JU, Schuler GD, Schriml LM, Sequeira E, Tatusova TA, Wagner L. Database resources of the National Center for Biotechnology. Nucleic Acids Res. 2003;31:28-33.

Wolf JC, Wolfe MJ. A brief overview of nonneoplastic hepatic toxicity in fish. Toxico Pathol. 2005;33:75-85.

Zhu C, Chen Z, Jiang Z. Expression, distribution and role of aquaporin water channels in human and animal stomach and intestines. Int J Mol Sci. 2016:17:1399

Zhu N, Feng X, He C, Gao H, Yang L, Ma Q, Guo L, Qiao Y, Yang H, Ma T. Defective macrophage function in aquaporin-3 deficiency. FASEB $J$. 2011:25:4233-9. 